\title{
Analytical Strategies for Determination and Environmental Impact Assessment of Inorganic Antimony Species in Natural Waters Using Hydride Generation Atomic Fluorescence Spectrometry (HG AFS)
}

\author{
Gerffeson S. dos Santos, ${ }^{a}$ Laiana O. B. Silva, ${ }^{a}$ Aníbal F. Santos Júnior, ${ }^{a, b}$ \\ Erik G. P. da Silva ${ }^{c}$ and Walter N. L. dos Santos ${ }^{*, a, d}$ \\ ${ }^{a}$ Departamento de Ciências Exatas e da Terra and ${ }^{b}$ Departamento de Ciências da Vida, \\ Universidade do Estado da Bahia, 41195-000 Salvador-BA, Brazil \\ 'Departamento de Ciências Exatas e Tecnológicas, Univesidade Estadual de Santa Cruz, \\ Campus Soane Nazaré de Andrade, 45662-900 Ilhéus-BA, Brazil \\ ${ }^{d}$ Instituto de Química, Universidade Federal da Bahia, Campus Ondina, \\ 40170-290 Salvador-BA, Brazil
}

\begin{abstract}
This study proposes an optimized procedure for the determination of inorganic antimony species in natural waters using hydride generation atomic fluorescence spectrometry (HG AFS) and continuous flow system. The variables of the hydride generation system, such as pre-reduction time, hydrochloric acid concentration and sodium tetrahydroborate concentration, were evaluated using full factorial design at two levels and Doehlert design. After optimized experimental conditions, the method allowed the determination of antimony with limits of detection and quantification of 9 and $30 \mathrm{ng} \mathrm{L}^{-1}$, respectively. The precision (RSD) of the method was $<5 \%$ and the accuracy was confirmed by the analysis of certified reference material (SLRS-4, River water for trace metals). The method was successfully applied for inorganic antimony speciation in water samples collected in Salvador City, Bahia State, Brazil. In mineral water, total Sb concentrations ranged from 0.26 to $0.30 \mu \mathrm{g} \mathrm{L}{ }^{-1}$, whereas the concentrations of $\mathrm{Sb}^{\mathrm{III}}$ were below $0.03 \mu \mathrm{g} \mathrm{L}-1$. On the other hand, in natural surface waters, the quantifiable concentration of total $\mathrm{Sb}$ and $\mathrm{Sb}^{\mathrm{III}}$ ranged from 0.41 to $1.23 \mu \mathrm{g} \mathrm{\textrm {L } ^ { - 1 }}$ and 0.23 to $1.04 \mu \mathrm{g} \mathrm{L}^{-1}$, respectively. The highest average concentrations of $\mathrm{Sb}$ were obtained in regions with the largest urban influence, ratifying the anthropogenic impact in water bodies.
\end{abstract}

Keywords: speciation, antimony, natural waters, multivariate optimization, HG AFS

\section{Introduction}

Antimony is considered, among other elements such as $\mathrm{As}, \mathrm{Pb}$ and $\mathrm{Hg}$, a toxic chemical element of global concern that has unknown biological functions. ${ }^{1,2}$ Its presence in aquatic environments is mainly due to anthropogenic activities and also as a result of natural processes, such as rock weathering and soil runoff. ${ }^{3}$ Among its applications, it is possible to mention the use of antimony in flame retardants, pharmaceutical products, as a component of brake linings and as a catalyst in the manufacture of polyethylene terephthalate (PET) containers. Antimony, in the environment, is mainly found in two oxidation states, $\mathrm{Sb}^{\mathrm{III}}$ and $\mathrm{Sb}^{\mathrm{V}}$, which can be present as different organic and inorganic species. Inorganic species are more

*e-mail: waltrs8@gmail.com toxic and $\mathrm{Sb}^{\mathrm{V}}$ compounds are less toxic than those of $\mathrm{Sb}^{\mathrm{III}}$ compounds. ${ }^{2,4-6}$

In recent years, an increase in the number of studies on total antimony determination and their inorganic species, $\mathrm{Sb}^{\mathrm{III}}$ and $\mathrm{Sb}^{\mathrm{V}}$, has been observed in environmental samples and drinking waters. These studies are encouraged by the toxicity of the element, as well as the considerable different toxicity of antimony species and by low permissible concentrations of this element in the environment, which are stipulated by regulatory agencies in many countries. The World Health Organization (WHO) ${ }^{7}$ establishes the concentration of $20 \mu \mathrm{g} \mathrm{L}^{-1}$ as a maximum permissible limit of antimony in drinking water. On the other hand, the maximum concentrations allowed in drinking water by the United States Environmental Protection Agency (USEPA) ${ }^{8}$ and Brazilian regulations $s^{9,10}$ are 6 and $5 \mu \mathrm{g} \mathrm{L}^{-1}$, respectively. For freshwater bodies, the maximum admissible limit is 
$5 \mu \mathrm{g} \mathrm{L}{ }^{-1}$, according to the resolution of the National Council of the Environment of Brazil (CONAMA). ${ }^{11}$ Thus, the development of reliable, sensitive and accurate analytical procedures is extremely important for the determination and monitoring of total $\mathrm{Sb}, \mathrm{Sb}^{\mathrm{III}}$ and $\mathrm{Sb}^{\mathrm{V}}$ in environment samples, as natural waters.

Among the detection techniques used for speciation antimony studies in natural waters, the most used are atomic absorption spectrometry (AAS) $)^{12-14}$ and atomic fluorescence spectrometry (AFS), coupled to hydride generation (HG) ${ }^{15-20}$ The popularity of hydride generation atomic fluorescence spectrometry (HG AFS) is growing, due to its low instrumental cost, when compared with sophisticated techniques, such as inductively coupled plasma mass spectrometry (ICP-MS) coupled to high performance liquid chromatography (HPLC), great sensitivity in the determination of antimony at trace levels and wide dynamic range. ${ }^{6}$ Wen and $\mathrm{Zhu}^{14}$ developed a method for antimony speciation, $\mathrm{Sb}^{\mathrm{III}}$ and $\mathrm{Sb}^{\mathrm{v}}$, in soil and water samples, using ultrasound-assisted emulsification of solidified floating organic drop microextraction (USE-SFODME) and electrothermal atomic absorption spectrometry (ETAAS). The concentrations of $\mathrm{Sb}^{\mathrm{II}}$ and $\mathrm{Sb}^{\mathrm{V}}$ were 0.37 and $1.05 \mu \mathrm{g} \mathrm{L}^{-1}$ for lake water and, for tap water, the concentrations of both species were below the detection limit $\left(9.89 \mathrm{ng} \mathrm{L}^{-1}\right)$. Wu et al..$^{20}$ performed the simultaneous speciation of inorganic $\mathrm{As}$ and $\mathrm{Sb}$ in natural water, using online solid-phase extraction and HG AFS, and a limit of detection of $2.1 \mathrm{ng} \mathrm{L}^{-1}$ was achieved for $\mathrm{Sb}^{\mathrm{III}}$. Sea water, river water, lake water and groundwater samples were analyzed, the highest concentration of total antimony was found in groundwater (0.271 $\mu \mathrm{g} \mathrm{L}{ }^{-1}$ ), and $0.213 \mu \mathrm{g} \mathrm{L}^{-1}$ corresponded to $\mathrm{Sb}^{\mathrm{III}}$.

Deng et al. ${ }^{15}$ performed antimony speciation using HG AFS and 8-hydroxyquinoline as a masking agent. The speciation analysis was conducted in surface waters of three lakes, and $\mathrm{Sb}^{\mathrm{III}}$ concentrations were low or nondetectable, whereas $\mathrm{Sb}^{\mathrm{v}}$ concentrations ranged from 39.6 to $72.5 \mathrm{ng} \mathrm{L}^{-1}$. Carneado et al. ${ }^{19}$ evaluated the influence of storage time and temperature on Sb migration from PET bottles into mineral water. Total antimony in mineral waters was determined using HG AFS and the speciation analysis was performed by high performance liquid chromatography hyphenated inductively coupled plasma mass spectroscopy (HPLC-ICP-MS). In this study, it was observed that $\mathrm{Sb}^{\mathrm{V}}$ was the predominant species in the measured water and that, when bottles were stored at $60^{\circ} \mathrm{C}$, significant amounts of $\mathrm{Sb}$ migrated into the water, exceeding the maximum content established by the European Union ${ }^{21}\left(5.0 \mu \mathrm{g} \mathrm{L}^{-1}\right)$ after 15 days of storage.

Thus, this paper reports a rapid and sensitive analytical method, without a separation/pre-concentration step, for the determination of total $\mathrm{Sb}$ and $\mathrm{Sb}^{\mathrm{III}}$ in mineral water and natural surface water, using continuous flow of hydride generation and atomic fluorescence spectrometry. Multivariate design was applied for the optimization of variables that influence the system. The concentrations of antimony determined in natural waters collected in Salvador, Bahia, Brazil, were evaluated and discussed, taking into account the national and international current regulations and other data reported in the literature.

\section{Experimental}

\section{Reagents and solutions}

All reagents used in the experiments were of analytical grade. The solutions were prepared using ultrapure water obtained by purification system of a Milli-Q system (Millipore, Bedford, MD, USA). Standard antimony solutions used in the experiments were prepared by diluting a $1000 \mathrm{mg} \mathrm{L}^{-1} \mathrm{Sb}^{\mathrm{v}}$ stock solution (Merck, Germany). A $3 \mathrm{~mol} \mathrm{~L}^{-1} \mathrm{HCl}$ solution used in all experiments was prepared from concentrated $\mathrm{HCl}\left(37 \% \mathrm{v} \mathrm{v}^{-1}\right.$, Merck). The reducing solution of $1.4 \%\left(\mathrm{~m} \mathrm{v}^{-1}\right)$ sodium tetrahydroborate was prepared daily by dissolving appropriate amounts of solid $\mathrm{NaBH}_{4}$ (Merck) in $0.5 \%\left(\mathrm{~m} \mathrm{v}^{-1}\right) \mathrm{NaOH}$ (Merck). For total $\mathrm{Sb}$ determination, pre-reducing solutions containing $2.0 \%\left(\mathrm{~m} \mathrm{v}^{-1}\right)$ ascorbic acid and $10 \%\left(\mathrm{~m} \mathrm{v}^{-1}\right)$ potassium iodide were used and daily prepared with ultrapure water. A certified reference material of river water to trace metal (SLSR-4) from the National Research Council of Canada (Ottawa, Canada) was used to evaluate de accuracy of the method.

\section{Natural water sample: collection and storage}

The proposed method was applied for the determination of total $\mathrm{Sb}$ and $\mathrm{Sb}^{\mathrm{III}}$ in mineral water and natural surface water samples. Four mineral water samples (M1; M2; M3 and M4) were purchased in supermarkets of Salvador (Bahia, Brazil). These samples were stored at room temperature until analysis in their own marketing containers. Ten samples of surface natural water were collected on the same day in different water bodies of Salvador (Figure 1). Two samples were collected in Abaeté Lake, five in the pond of Pituaçú Metropolitan Park and three in Tororó Lake. These samples were collected in decontaminated plastic bottles and, after collection, the samples were placed in a refrigerated container and transported to the laboratory, where they were analyzed on the same day.

Abaeté Lake is a pond much used for entertainment and tourism and is located in the environmental protection area 


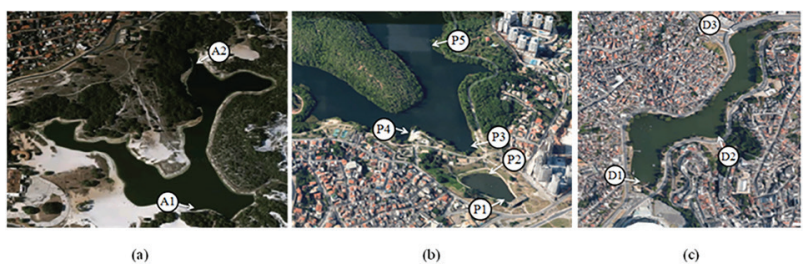

Figure 1. Surface natural water samples collected from: (a) Abaeté Lake; (b) Pituaçú Metropolitan Park; (c) Tororó Lake. Images taken by Google Maps, 2016.

of the Metropolitan Park of Ponds and Dunes of Abaeté in Salvador, Bahia, Brazil. Pond of Pituaçú is located in Pituaçú Metropolitan Park, which is situated on the seafront and corresponds to the largest ecological reserve in the city of Salvador, Bahia. Tororó Lake is a lake artificially located in the city center and limited by different neighborhoods. It is a well wooded sports and leisure area.

Instrumentation

An Aurora Lumina 3300 atomic fluorescence spectrometer (Vancouver, Canada) fitted with an antimony hollow cathode lamp (HCL) of high intensity and with a quartz tube atomizer, was used to measure antimony fluorescence intensity. Argon with a purity degree of 99.996\% (White Martins, São Paulo, Brazil) was used as the carrier gas of the generated hydride. The experimental conditions and operating parameters are summarized in Table 1.

Table 1. Settings and operating conditions of HG AFS for Sb determination

\begin{tabular}{|c|c|}
\hline Parameter & Condition \\
\hline Atomizer height / mm & 8 \\
\hline Sb-HCL, wavelength / nm & 217 \\
\hline Lamp current / mA & 100 \\
\hline Flame composition & $\mathrm{H}_{2} /$ air \\
\hline Argon flow rate (carrier gas) / $\left(\mathrm{mL} \mathrm{min}^{-1}\right)$ & 400 \\
\hline Argon flow rate (auxiliary gas) / $\left(\mathrm{mL} \mathrm{min}^{-1}\right)$ & 800 \\
\hline $\mathrm{NaBH}_{4}$ flow rate (reducing solution) / $\left(\mathrm{mL} \mathrm{min}{ }^{-1}\right)$ & 4 \\
\hline Sample flow rate $/\left(\mathrm{mL} \mathrm{min}^{-1}\right)$ & 4 \\
\hline Read time / s & 6 \\
\hline
\end{tabular}

\section{General procedure}

The developed method used a continuous flow system for hydride generation. In this system, a peristaltic pump was used to drive the acidified sample and $1.4 \%\left(\mathrm{~m} \mathrm{v}^{-1}\right)$ $\mathrm{NaBH}_{4}$ solution, both at a flow rate of $4 \mathrm{~mL} \mathrm{~min}{ }^{-1}$, for a hydride generator, simultaneously. The volatile antimony hydride $\left(\mathrm{SbH}_{3}\right)$ and the hydrogen formed were transported to gas-liquid separator and to the quartz cell (atomizer) with the aid of argon and finally, after the decomposition of the hydride in $\mathrm{H}_{2}$ /air flame, $\mathrm{Sb}$ was detected by AFS. The speciation analysis is based on the different kinetics of antimony hydrides generation from their different inorganic species. The inorganic $\mathrm{Sb}^{\mathrm{III}}$ species reacts faster with sodium tetrahydroborate, preferably forming $\mathrm{SbH}_{3}$.

For the determination of total $\mathrm{Sb}, 3.0 \mathrm{~mL}$ of the water sample, as well as $3.0 \mathrm{~mL}$ of $3 \mathrm{~mol} \mathrm{~L}^{-1} \mathrm{HCl}$ and $1 \mathrm{~mL}$ of prereducing solution $(10 \% \mathrm{KI}+2 \%$ ascorbic acid), were added into a $10 \mathrm{~mL}$ volumetric flask. After $20 \mathrm{~min}$, ultrapure water was added to reach a volume of $10 \mathrm{~mL}$ and this solution was then analyzed using the continuous flow system for hydride generation and AFS. For the determination of $\mathrm{Sb}^{\text {III }}, 3.0 \mathrm{~mL}$ of the water sample were acidified with $3 \mathrm{~mL}$ of $3 \mathrm{~mol} \mathrm{~L}^{-1} \mathrm{HCl}$ and diluted with $6 \mathrm{~mL}$ ultrapure water in a volumetric flask $(10 \mathrm{~mL})$, and then subjected to analysis. $\mathrm{Sb}^{\mathrm{V}}$ was determined by the difference between the concentrations of total $\mathrm{Sb}$ and $\mathrm{Sb}^{\mathrm{III}}$.

\section{Results and Discussion}

Optimization of the experimental conditions for hydride generation

The experimental conditions were evaluated, firstly using a two-level full factorial design, which included the following factors: pre-reduction time (RT), hydrochloric acid concentration $[\mathrm{HCl}]$ and sodium tetrahydroborate concentration $\left[\mathrm{NaBH}_{4}\right]$. The evaluated chemometric response was fluorescence intensity (FI), and the real and coded values of the factors along with the responses are shown in Table 2. All experiments were performed in a random order and employing $3 \mu \mathrm{g} \mathrm{L^{-1 }} \mathrm{Sb}^{\text {III }}$ solutions.

Table 2. Full two-level factorial design, optimization of the procedure for Sb determination by HG AFS ${ }^{a}$

\begin{tabular}{lcccc}
\hline Experiment & $\begin{array}{c}\mathrm{HCl} / \\
\left(\mathrm{mol} \mathrm{L}^{-1}\right)\end{array}$ & $\begin{array}{c}\mathrm{NaBH}_{4} / \\
\%\left(\mathrm{~m} \mathrm{v}^{-1}\right)\end{array}$ & $\begin{array}{c}\mathrm{RT} / \\
\mathrm{min}\end{array}$ & FI \\
\hline 1 & $-1(3)$ & $-1(1)$ & $-1(10)$ & 178.4 \\
2 & $-1(3)$ & $-1(1)$ & $1(30)$ & 167.5 \\
3 & $-1(3)$ & $1(3)$ & $-1(10)$ & 225.7 \\
4 & $-1(3)$ & $1(3)$ & $1(30)$ & 218.1 \\
5 & $1(5)$ & $-1(1)$ & $-1(10)$ & 86.6 \\
6 & $1(5)$ & $-1(1)$ & $1(30)$ & 91.0 \\
7 & $1(5)$ & $1(3)$ & $-1(10)$ & 195.6 \\
8 & $1(5)$ & $1(3)$ & $1(30)$ & 189.2 \\
$9(\mathrm{CP})$ & $0(4)$ & $0(2)$ & $0(20)$ & 137.5 \\
$10(\mathrm{CP})$ & $0(4)$ & $0(2)$ & $0(20)$ & 135.7 \\
$11(\mathrm{CP})$ & $0(4)$ & $0(2)$ & $0(20)$ & 137.8 \\
\hline
\end{tabular}

${ }^{\mathrm{a}}(\mathrm{CP})$ : central point. $\mathrm{RT}$ : pre-reduction time; FI: fluorescence intensity. 
The obtained data were processed using the Statistica 7.0 computer program. An evaluation of these results, considering the studied experimental dominions, revealed that the concentrations of sodium tetrahydroborate (effect: $76.27 \pm 3.45$ ) and hydrochloric acid (effect: $-56.82 \pm 3.43$ ) were the factors that had the greatest significant effects on the generation of antimony hydrides. The interaction of these factors was also significant (effect: $27.32 \pm 3.46$ ), but the pre-reduction effect and all other interactions had a lower influence on the system. On the basis of these results, a Doehlert design, involving $\mathrm{HCl}$ and $\mathrm{NaBH}_{4}$ concentrations, was performed, to find the critical conditions for antimony hydride generation. All experiments were conducted by fixing the pre-reduction time in twenty minutes and investigating the most significant factor (concentration of $\mathrm{NaBH}_{4}$ ) in five levels and the concentration of $\mathrm{HCl}$ in three levels. The coded and real values established in the Doehlert design are shown in Table 3.

Table 3. Doehlert design, optimization of the procedure for $\mathrm{Sb}$ determination by $\mathrm{HG} \mathrm{AFS}^{\mathrm{a}}$

\begin{tabular}{lccc}
\hline Experiment & $\mathrm{HCl} /\left(\mathrm{mol} \mathrm{L}^{-1}\right)$ & $\mathrm{NaBH}_{4} / \%\left(\mathrm{~m} \mathrm{v}^{-1}\right)$ & $\mathrm{FI}$ \\
\hline 1 & $0.866(5)$ & $0.5(1.8)$ & 367 \\
2 & $0.866(5)$ & $-0.5(1.4)$ & 660 \\
3 & $0(4)$ & $-1(1.2)$ & 762 \\
4 & $-0.866(3)$ & $-0.5(1.4)$ & 787 \\
5 & $-0.866(3)$ & $0.5(1.8)$ & 434 \\
6 & $0(4)$ & $1(2.0)$ & 167 \\
$7(\mathrm{CP})$ & $0(4)$ & $0(1.6)$ & 651 \\
$8(\mathrm{CP})$ & $0(4)$ & $0(1.6)$ & 643 \\
$9(\mathrm{CP})$ & $0(4)$ & $0(1.6)$ & 652 \\
\hline
\end{tabular}

${ }^{a}(C P)$ : central point. FI: fluorescence intensity.

After processing the obtained results in a statistical program, a quadratic model without lack of fit was generated, which exhibited a response surface with a maximum fluorescence intensity at the experimental conditions of $3.07 \mathrm{~mol} \mathrm{~L}^{-1} \mathrm{HCl}$ and $1.24 \%\left(\mathrm{~m} \mathrm{v}^{-1}\right) \mathrm{NaBH}_{4}$. Considering the optimization studies, the critical conditions for antimony hydride generation using continuous flow system and AFS were 20 min for pre-reduction time, $3 \mathrm{~mol} \mathrm{~L}^{-1}$ for hydrochloric acid concentration and $1.2 \%$ for sodium tetrahydroborate concentration.

\section{Analytical characteristics of the method}

Several analytical parameters, such as limits of detection and quantification (LOQ), sensitivity, linearity and precision, were evaluated for the proposed method. With the use of optimized experimental conditions, the method allowed the direct determination of antimony in natural waters with limits of detection and quantification of 9 and $30 \mathrm{ng} \mathrm{L}^{-1}$, respectively. The precision of the method in terms of relative standard deviation $(\mathrm{RSD}, \mathrm{n}=7$ ) was $3.3,2.8$ and $2.1 \%$ for standard antimony solutions of 5,7 and $10 \mu \mathrm{g} \mathrm{L}^{-1}$, respectively, and $4.4 \%$ for certified reference samples of river water with an antimony content of $0.23 \pm 0.04 \mu \mathrm{g} \mathrm{L}^{-1}$, showing good repeatability data. The calibration curve was linear in the range from $30 \mathrm{ng} \mathrm{L}^{-1}$ to $10.0 \mu \mathrm{g} \mathrm{L}{ }^{-1}$, which showed the following regression equation $\mathrm{FI}=71.77 \mathrm{C}_{\mathrm{Sb}}+11.52\left(\right.$ where $\mathrm{C}_{\mathrm{Sb}}$ is reference at antimony concentration), with a correlation coefficient (r) of 0.9993. The accuracy of the proposed method was evaluated by the analysis of certified reference samples of river water (SLRS-4). There are no certified reference material available for analyses of speciation for $\mathrm{Sb}^{\mathrm{II}}$. Maybe the predominance of $\mathrm{Sb}^{\mathrm{V}}$ in water samples is caused by species transformation after the sampling. The problematic are on the instability of $\mathrm{Sb}^{\mathrm{III}}$ regarding oxidation. In certified reference material only the total $\mathrm{Sb}$ is available and this was used. The obtained result demonstrates agreement between the certificate $\left(0.23 \pm 0.04 \mu \mathrm{g} \mathrm{L}^{-1}\right)$ and found values $\left(0.30 \pm 0.09 \mu \mathrm{g} \mathrm{L}^{-1}\right)$, indicating that the proposed method is reliable and can be applied in studying matrices.

\section{Application to natural waters}

The proposed method was applied for speciation analysis of inorganic antimony in water samples. The chemical speciation of antimony consisted in the determination of total $\mathrm{Sb}$ after adding a pre-reducing solution (KI with ascorbic acid) into the sample and $\mathrm{Sb}^{\text {III, }}$, without adding this solution into the water sample. The concentration of $\mathrm{Sb}^{\mathrm{v}}$ is achieved by the difference between the concentrations of total $\mathrm{Sb}$ and $\mathrm{Sb}^{\mathrm{III}}$ in the analyzed samples. The results obtained for mineral and natural surface waters are shown in Table 4.

The results demonstrate that, for the analyzed mineral water, the concentration of total $\mathrm{Sb}$ that ranged from $0.26 \pm 0.04$ to $0.30 \pm 0.08 \mu \mathrm{g} \mathrm{L}^{-1}$ was lower than the maximum permissible values endorsed by the USEPA, ${ }^{8}$ which provides a reference value of $6 \mu \mathrm{g} \mathrm{L}^{-1}$, as well as by Brazilian regulations, ${ }^{9,10}$ which stipulate a value of $5 \mu \mathrm{g} \mathrm{L}^{-1}$, both for potable and bottled water. With the use of the developed method, it was not possible to estimate $\mathrm{Sb}^{\mathrm{III}}$ concentrations in the samples, which were below the limit of quantification $\left(0.03 \mu \mathrm{g} \mathrm{L}^{-1}\right)$. These results are in agreement with data reported in the literature for mineral water, for which average concentrations that ranged from 0.123 to $0.137 \mu \mathrm{g} \mathrm{L} \mathrm{L}^{-1}$ for total $\mathrm{Sb}$ and 0.029 to $0.027 \mu \mathrm{g} \mathrm{L}^{-1}$ for $\mathrm{Sb}^{\mathrm{III}}$ was observed, when storage time in PET containers 
Table 4. Determination of total $\mathrm{Sb}$ and $\mathrm{Sb}^{\mathrm{III}}$ in mineral and natural surface waters collected in Salvador, Brazil $(\mathrm{n}=3)$

\begin{tabular}{|c|c|c|}
\hline & \multicolumn{2}{|c|}{ Sb determined / $\left(\mu \mathrm{g} \mathrm{L}{ }^{-1}\right)$} \\
\hline & Total Sb & $\mathrm{Sb}^{\mathrm{III}}$ \\
\hline \multicolumn{3}{|l|}{ Mineral water sample } \\
\hline Mineral water 1 (M1) & $0.27 \pm 0.04$ & $<0.03(\mathrm{LOQ})$ \\
\hline Mineral water 2 (M2) & $0.29 \pm 0.04$ & $<0.03(\mathrm{LOQ})$ \\
\hline Mineral water 3 (M3) & $0.26 \pm 0.06$ & $<0.03$ (LOQ) \\
\hline Mineral water 4 (M4) & $0.30 \pm 0.08$ & $<0.03(\mathrm{LOQ})$ \\
\hline \multicolumn{3}{|c|}{ Natural surface water sample } \\
\hline Abaeté Lake (A1) & $0.41 \pm 0.09$ & $<0.03(\mathrm{LOQ})$ \\
\hline Abaeté Lake (A2) & $0.83 \pm 0.10$ & $<0.03(\mathrm{LOQ})$ \\
\hline Pond of Pituaçú (P1) & $0.82 \pm 0.31$ & $<0.03(\mathrm{LOQ})$ \\
\hline Pond of Pituaçú (P2) & $1.10 \pm 0.07$ & $<0.03(\mathrm{LOQ})$ \\
\hline Pond of Pituaçú (P3) & $0.62 \pm 0.21$ & $0.23 \pm 0.11$ \\
\hline Pond of Pituaçú (P4) & $0.70 \pm 0.12$ & $<0.03(\mathrm{LOQ})$ \\
\hline Pond of Pituaçú (P5) & $0.87 \pm 0.17$ & $0.27 \pm 0.09$ \\
\hline Tororó Lake (D1) & $1.22 \pm 0.09$ & $<0.03(\mathrm{LOQ})$ \\
\hline Tororó Lake (D2) & $0.99 \pm 0.15$ & $0.33 \pm 0.07$ \\
\hline Tororó Lake (D3) & $1.23 \pm 0.11$ & $1.04 \pm 0.18$ \\
\hline
\end{tabular}

LOQ: limit of quantification.

was extended. Extended storage results in sample contamination with $\mathrm{Sb}$ and in a significant conversion of $\mathrm{Sb}^{\mathrm{III}}$ to $\mathrm{Sb}^{\mathrm{V}}$, the less toxic species. ${ }^{13}$

For natural surface water samples, the total Sb content ranged from $0.41 \pm 0.09$ to $1.23 \pm 0.11 \mu \mathrm{g} \mathrm{L} \mathrm{L}^{-1}$ and, for $\mathrm{Sb}^{\mathrm{III}}$, it ranged from $<0.03$ (LOQ) to $1.04 \pm 0.18 \mu \mathrm{g} \mathrm{L}^{-1}$. The values found in this study are similar to those reported for natural waters in other studies, ${ }^{12,14,22}$ although the distribution and speciation of antimony in aquatic systems depend on the nearness of pollution sources and the physicochemical conditions of the environment. In general, the level of $\mathrm{Sb}^{\mathrm{V}}$ depends on the redox status of the aquatic environment and $\mathrm{Sb}^{\mathrm{III}}$ is characteristic of water with a low oxygen content. ${ }^{22-26}$ Finally, antimony concentrations did not exceed the maximum admissible content in freshwater bodies established by the Brazilian regulation $\left(5.0 \mu \mathrm{g} \mathrm{L}^{-1}\right){ }^{11}$

Average total Sb content in Abaeté Lake was $0.62 \mu \mathrm{g} \mathrm{L}{ }^{-1}$, presenting the lowest average among the locations studied. Pond of Pituaçu samples had an average value equivalent to $0.822 \mu \mathrm{g} \mathrm{L}{ }^{-1}$. Already, Tororó Lake samples had the highest average concentration of total $\mathrm{Sb}\left(1.15 \mu \mathrm{g} \mathrm{L}^{-1}\right)$. This result is likely because the Tororó Lake is the region with the largest urban influence and anthropogenic impact.

\section{Conclusions}

The present study presented a sensitive, accurate, fast and reliable procedure for the non chromatographic speciation of inorganic antimony species in natural waters using continuous flow system and HG AFS. The multivariate techniques used in this study provided a quick and efficient optimization of the investigated factors that influence the determination of antimony using hydride generation. The concentrations of total $\mathrm{Sb}$ and $\mathrm{Sb}^{\mathrm{II}}$ found in the analyzed natural surfaces and mineral waters were below the recommended by national and international regulatory agencies, and consistent with the results obtained by other studies involving watercourse bodies and mineral water.

\section{Acknowledgments}

The authors gratefully acknowledge the Brazilian agencies Fundação de Amparo à Pesquisa do Estado da Bahia (FAPESB), Conselho Nacional de Desenvolvimento Científico e Tecnológico (CNPq) and Coordenação de Aperfeiçoamento de Pessoal de Nível Superior (CAPES) for grants and fellowships.

\section{References}

1. Amarasiriwardena, D.; Wu, F.; Microchem. J. 2011, 97, 1.

2. Filella, M.; Williams, P.; Belzile, N.; Environ. Chem. 2009, 6, 95.

3. Filella, M.; Belzile, N.; Chen, Y. W.; Earth-Sci. Rev. 2002, 57 , 125.

4. Júnior, M. M. S.; Leao, D. J. L.; Moreira, I. T. A.; de Oliveira, O. M. C.; Queiroz, A. F. S.; Ferreira, S. L. C.; Environ. Sci. Pollut. Res. 2015, 22, 8386.

5. Smichowski, P.; Talanta 2008, 75, 2.

6. Ferreira, S. L. C.; dos Santos, W. N. L.; dos Santos, I. F.; Júnior, M. M. S.; Silva, L. O. B.; Barbosa, U. A.; de Santana, F. A.; Queiroz, A. F. S.; Microchem. J. 2014, 114, 22.

7. World Health Organization (WHO); Guidelines for DrinkingWater Quality, $4^{\text {th }}$ ed.; WHO Library Cataloguing-in-Publication Data: Switzerland, 2011.

8. US Environmental Protection Agency (USEPA); 816-F-090004; National Primary Drinking Water Standards and National Secondary Drinking Water Standards; EPA's Office of Water: Washington, D.C., 2009. Available at https://safewater.zendesk. com/hc/en-us/articles/212077917-4-What-are-EPA-s-drinkingwater-regulations-for-antimony-, accessed in April 2017.

9. Brasil, Ministério da Saúde; Portaria No. 518, de 25 de Março de 2004, Estabelece os Procedimentos e Responsabilidades Relativos ao Controle e Vigilância da Qualidade da Água para Consumo Humano e seu Padrão de Potabilidade, e dá outras providências; Editora MS: Brasília, DF, 2005. Available at http://bvsms.saude.gov.br/bvs/publicacoes/portaria_518_2004. pdf, accessed in April 2017.

10. Agência Nacional de Vigilância Sanitária (ANVISA); Resolução RDC No. 274, de 22 de setembro de 2005, Aprova 
o Regulamento Técnico para Águas Envasadas e Gelo; D.O.U.: Brasília, DF, 2005. Available at http://portal.anvisa.gov.br/ documents/33916/394219/RDC_274_2005.pdf/19d98e61fa3b-41df-9342-67e0167bf550, accessed in April 2017.

11. Conselho Nacional do Meio Ambiente (CONAMA); Resolution No. 357, 17 de Março de 2005, Dispõe sobre a Classificação dos Corpos de Água e Diretrizes Ambientais para o seu Enquadramento, bem como Estabelece as Condições e Padrões de Lançamento de Efluentes, e Dá Outras Providências; D.O.U.: Brasília, DF, 2005. Available at http://www.mma.gov.br/port/ conama/legiabre.cfm?codlegi=459, accessed in April 2017.

12. Eftekhari, M.; Chamsaz, M.; Arbab-Zavar, M. H.; Eftekhari, A.; Environ. Monit. Assess. 2015, 187, 4129.

13. Shakerian, F.; Dadfarnia, S.; Shabani, A. M. H.; Abadi, M. N. A.; Food Chem. 2014, 145, 571.

14. Wen, S.; Zhu, X.; Talanta 2013, 115, 814.

15. Deng, T. L.; Chen, Y. W.; Belzile, N.; Anal. Chim. Acta 2001, 432, 293.

16. Sayago, A.; Beltran, R.; Recamales, M. A. F.; Gomez-Ariza, J. L.; J. Anal. At. Spectrom. 2002, 17, 1400.

17. Semenova, N. V.; Leal, L. O.; Forteza, R.; Cerdà, V.; Anal. Chim. Acta 2005, 530, 113.

18. Wang, X. W.; Li, X. K.; Zhang, X.; Qian, S. H.; J. Anal. At. Spectrom. 2014, 29, 1944.

19. Carneado, S.; Hernández-Nataren, E.; López-Sánchez, J. F.; Sahuquillo, A.; Food Chem. 2015, 166, 544.
20. Wu, H.; Wang, X.; Liu, B.; Liu, Y.; Li, S.; Lu, J.; Tian, J.; Zhao, W.; Yang, Z.; Spectrochim. Acta, Part B 2011, 66, 74.

21. European Comission; Council Directive 98/83/EC of November 3, 1998 on the Quality of Water Intended for Human Consumption; Official Journal of the European Communities L 330, December 5, 1998, p. 32-54. Available at http://eur-lex. europa.eu/LexUriServ/LexUriServ.do?uri=OJ:L:1998:330:00 32:0054:EN:PDF, accessed in April 2017.

22. Jabłońska-Czapla, M.; Szopa, S.; Grygoyć, K.; Łyko, A.; Michalski, R.; Talanta 2014, 120, 475.

23. Cornelis, R.; Caruso, J.; Crews, H.; Heumann, K.; Handbook of Elemental Speciation II: Species in the Environment, Food, Medicine \& Occupational Health; John Wiley \& Sons: England, 2005.

24. Smichowski, P.; Madrid, Y.; Camara, C.; Fresenius' J. Anal. Chem. 1998, 360, 623.

25. Nash, M. J.; Maskall, J. E.; Hill, S. J.; J. Environ. Monit. 2000, 2, 97.

26. Ferreira, S. L. C.; Santos, W. N. L.; Santos, I. F.; Junior, M. M. S.; Silva, L. O. B.; Barbosa, U. A.; Santana, F. A.; Queiroz, A. F. S.; Microchem. J. 2014, 114, 22.

Submitted: April 20, 2017

Published online: July 7, 2017 